\title{
Prominent Expression of Two Forms of Glutamate Decarboxylase in the Embryonic and Early Postnatal Rat Hippocampal Formation
}

\author{
Shannon T. Dupuy ${ }^{1}$ and Carolyn R. Houser ${ }^{1,2,3}$ \\ ${ }^{1}$ Department of Neurobiology and ${ }^{2} B r a i n$ Research Institute, University of California, Los Angeles, California 90095, and \\ ${ }^{3}$ Neurology and Research Services, VA Medical Center, Los Angeles, California 90073
}

Immunohistochemical methods were used to determine the earliest times of detection for two forms of glutamate decarboxylase (GAD67 and GAD65) in the embryonic and early postnatal rat hippocampal formation and to determine whether their distribution patterns differed from each other and from those of the adult. Both GAD67- and GAD65-containing neurons were observed as early as embryonic day 17 (E17)-E18 in the hippocampus and E19 in the dentate gyrus, and this was substantially earlier than GAD had been detected previously in the hippocampal formation. The two GAD isoforms displayed very similar distribution patterns, but these patterns were distinctly different from those of the adult. From E17 to E20, GAD67 and GAD65 were expressed in neuronal cell bodies throughout the hippocampal and dentate marginal zones (future dendritic layers), and relatively few existed within the principal cell body layers, where GAD-positive neurons are frequently concentrated in the adult. At E21 to postnatal day 1 (P1), there was a sudden shift from a predominance of GAD-containing cell bodies within the developing dendritic regions to a meshwork of
GAD-positive processes with terminal-like varicosities in these same regions. This pattern also contrasted with that of the adult, in which GAD-labeled terminals are highly concentrated in the principal cell layers. Electron microscopic observations of the GAD-labeled processes at P1 confirmed their axon-like appearance and demonstrated that the immunoreactivity was consistently localized in vesicle-filled regions that were often closely apposed to and, in some instances, established synaptic contacts with dendritic profiles.

The present identification of an early abundance of GADcontaining structures in the hippocampal formation and the marked change in their distribution during development complement recent observations of developmental changes in the functioning of the GABA system and provide additional support for the early involvement of this neurotransmitter system in hippocampal development.

Key words: glutamic acid decarboxylase; GAD; GABA; development; hippocampus; dentate gyrus; immunohistochemistry
Both histochemical and physiological findings suggest that the GABA system may have an important role in the early development of the hippocampal formation. Data from studies that have used a combination of $\left[{ }^{3} \mathrm{H}\right]$ thymidine autoradiography and glutamic acid decarboxylase (GAD) immunohistochemistry (IHC) indicate that many of the GABAergic neurons in the adult hippocampal formation are generated early in development (Amaral and Kurz, 1985; Lübbers et al., 1985; Soriano et al., 1986, 1989a,b), and, in fact, many of their birthdates precede those of the principal cells of the hippocampal formation (Altman and Das, 1965; Bayer and Altman, 1974; Schlessinger et al., 1975, 1978; Bayer, 1980; Stanfield and Cowan, 1988; Altman and Bayer, 1990a,b,c). More recently, the early presence of GABAimmunoreactive neurons within the developing hippocampal formation has been reported (Lauder et al., 1986; Rozenberg et al., 1989; Soriano et al., 1994). Functionally, in the hippocampus of neonatal animals, GABA induces strong depolarizing effects in CA1 and CA3 pyramidal cells (Mueller et al., 1984; Janigro and Schwartzkroin, 1988; Ben-Ari et al., 1989; Cherubini et al., 1991)

\footnotetext{
Received June 11, 1996; revised Aug. 12, 1996; accepted Aug. 15, 1996.

This research was supported by National Institutes of Health Grant NS33360. We thank Dr. David Gottlieb for generously providing the GAD-6 antibody, Dr. Allan Tobin for providing the K2 antiserum, Dr. Nianhui Zhang for assisting with the electron microscopy, Bruce Havens for assistance with the immunohistochemistry, and Donald Chang for excellent photographic work.

Correspondence should be addressed to Dr. Carolyn R. Houser, BRI 73-364 CHS, Brain Research Institute, UCLA, Los Angeles, CA 90095-1761.

Copyright (C) 1996 Society for Neuroscience 0270-6474/96/166919-14\$05.00/0
}

at a time when very few glutamate responses can be elicited. Furthermore, a GABA-induced rise in intracellular $\mathrm{Ca}^{2+}$ has been observed in developing hippocampal neurons (Obrietan and van den Pol, 1995), and this could be associated with trophic actions of GABA in the developing hippocampus (Barbin et al., 1993).

Despite strong evidence for the early development and function of GABA neurons in the hippocampus, a similar early presence of $\mathrm{GAD}$, the synthesizing enzyme for GABA, has not been demonstrated, and this has led to the suggestion that an alternate pathway for GABA synthesis might be used at early stages of development (Lauder et al., 1986; Swann et al., 1989). Previous immunohistochemical studies have not detected GAD-labeled structures in the rat hippocampus until postnatal days 2-5 (P2P5), the earliest ages examined (Seress and Ribak, 1988; Nitsch et al., 1990).

With the recent identification of two isoforms of GAD, GAD67 and GAD65 (Erlander and Tobin, 1991; Erlander et al., 1991), the possibility arises that the two forms could have different patterns of development. In fact, it has been suggested that in some developing brain regions such as the cerebellum, striatum, and spinal cord, the time of appearance of GAD67 and GAD65 may differ (Greif et al., 1991, 1992; Behar et al., 1993). Thus, immunohistochemical methods were used in the present study to evaluate the temporal and spatial patterns of development of GAD67 and GAD65 in the embryonic and early postnatal rat hippocampal formation. The following questions were addressed: What is the 
earliest time that GAD67 and GAD65 can be detected in the developing hippocampal formation? Do the GAD67 and GAD65 distribution patterns within the developing hippocampal formation differ from each other and from those of the adult? What are the morphological characteristics of the early-appearing GADcontaining structures in the developing hippocampal formation?

A preliminary report of some of the findings has been published (Dupuy and Houser, 1995).

\section{MATERIALS AND METHODS}

\section{Experimental animals}

Sprague Dawley rats (Harlan Sprague Dawley, Indianapolis, IN) from 17 different litters were used in these studies. The majority of the animals were studied during the embryonic period, but early postnatal (P1) and adult rats were also used. Female rats were mated overnight, and vaginal smears were taken the following morning to verify insemination. The day a positive smear was obtained was recorded as embryonic day 0 (E0). Birth usually occurred on E22, which was designated as P0.

For the light microscopic immunohistochemical studies, E16-E21 embryos, P1 pups, and adult (150-250 gm) animals were used, and tissue was obtained from two to five animals at each of these ages. Tissue from two P1 animals was used for the electron microscopic study.

\section{Light microscopy}

Tissue preparation. Pregnant rats were anesthetized with sodium pentobarbital $(60 \mathrm{mg} / \mathrm{kg}$, i.p.) before removal of embryos from the uterus. Embryos were briefly placed in cold oxygenated Gey's balanced salt solution (Freshney, 1987) before perfusion. Young postnatal animals were deeply anesthetized by ether inhalation, and adults were anesthetized by sodium pentobarbital $(60 \mathrm{mg} / \mathrm{kg}$, i.p.) before perfusion. All animals were perfused intracardially with a freshly prepared fixative solution of $4 \%$ paraformaldehyde in $0.12 \mathrm{~m}$ sodium phosphate buffer, $\mathrm{pH}$ 7.3. All embryonic and young postnatal animals received $50-100 \mathrm{ml}$ of fixative, whereas adult animals received $150-250 \mathrm{ml}(1 \mathrm{ml} / \mathrm{gm}$ body weight) of fixative. After perfusion, the rats were kept for $1 \mathrm{hr}$ at $4^{\circ} \mathrm{C}$. The brains were then removed from the skull, post-fixed in the same fixative for $1 \mathrm{hr}$ at room temperature (RT), rinsed in sodium phosphate buffer for $1.5 \mathrm{hr}$, and cryoprotected in a $20-30 \%$ sucrose solution at $4^{\circ} \mathrm{C}$ overnight. Blocks of forebrain containing the hippocampal formation were made in the coronal plane and quickly frozen on dry ice. Free-floating sections $(20-30 \mu \mathrm{m})$ to be processed for GAD67 or GAD65 IHC were cut on a cryostat and stored at $4^{\circ} \mathrm{C}$ in $0.1 \mathrm{M}$ Tris buffer, $\mathrm{pH}$ 7.3. All sections processed for IHC were from the middle portion of the dorsal hippocampal formation.

IHC for GAD67 and GAD65. The polyclonal antiserum K2 (Kaufman et al., 1991) was used to localize GAD67. This antiserum predominantly recognizes GAD67 on Western blots (Kaufman et al., 1991; Esclapez et al., 1994) and was generated in a rabbit after injection of GAD67 that was produced in a bacterial expression system from a cloned feline GAD cDNA (Kaufman et al., 1986, 1991; Kobayashi et al., 1987).

The monoclonal antibody GAD-6, obtained by Chang and Gottlieb (1988), was used to localize GAD65. This antibody selectively recognizes GAD65 on Western blots (Chang and Gottlieb, 1988; Kaufman et al., 1991; Esclapez et al., 1994) and was produced by a GAD-6 hybridoma line obtained after immunization of a mouse with rat brain GAD (Chang and Gottlieb, 1988).

Free-floating sections were processed for GAD67 and GAD65 IHC with unlabeled K2 and GAD-6 antibodies, respectively, and standard avidin-biotin immunolabeling techniques (Vectastain Elite ABC, Vector Laboratories, Burlingame, CA). Sections were rinsed for $20 \mathrm{~min}$ in $0.02 \mathrm{M}$ potassium PBS (KPBS) containing (in mM): $16.5 \mathrm{~K}_{2} \mathrm{HPO}_{4}, 3.5 \mathrm{KH}_{2} \mathrm{PO}_{4}$, $150 \mathrm{NaCl}, \mathrm{pH} 7.4$, and then incubated for $1 \mathrm{hr}$ at RT in the same buffer containing 3\% normal goat serum (GAD67-IHC) or normal horse serum (GAD65-IHC). After this blocking step, sections were incubated for $16 \mathrm{hr}$ at RT in K2 antiserum diluted 1:12,000 to 1:16,000 in KPBS containing $1 \%$ normal goat serum (GAD67-IHC) or in GAD-6 antibody diluted 1:100 in KPBS with 1\% normal horse serum (GAD65-IHC). After these incubations, sections were rinsed in KPBS for 20 min and then incubated for $1 \mathrm{hr}$ at RT in biotinylated goat anti-rabbit $\mathrm{IgG}$ or horse anti-mouse IgG diluted 1:200 with KPBS containing 1\% normal goat or horse serum. Tissues were then rinsed for $20 \mathrm{~min}$ in KPBS and incubated for $1 \mathrm{hr}$ at RT with an avidin-biotin-peroxidase solution (1:100) prepared in KPBS.

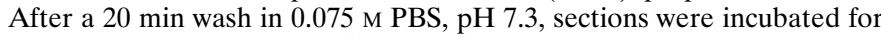
$12-15 \mathrm{~min}$ either in $0.06 \% 3,3^{\prime}$-diaminobenzidine tetrahydrochloride (DAB) and $0.006 \% \mathrm{H}_{2} \mathrm{O}_{2}$ diluted in PBS or $0.04 \%$ 3-amino-9-ethylcarbazole (AEC) in $3.3 \%$ dimethyl formamide and $0.015 \% \mathrm{H}_{2} \mathrm{O}_{2}$ diluted in acetate buffer ( $30 \mathrm{~mm} \mathrm{Na}$ acetate, $21 \mathrm{~mm}$ acetic acid, $\mathrm{pH} 4.8$ ). The sections that were processed with DAB were rinsed in PBS for $20 \mathrm{~min}$, and some were then treated for $30 \mathrm{sec}$ with a $0.01-0.05 \%$ osmium tetroxide solution. They were then rinsed in PBS, mounted on gelatincoated slides, dehydrated, and coverslipped with Permount mounting medium (Fisher Scientific, Tustin, CA). The sections processed with AEC were similarly prepared but coverslipped in an aqueous mounting medium (Crystal/Mount, Biomeda, Foster City, CA).

Immunohistochemical controls. Controls for GAD IHC included incubations in preimmune rabbit serum for $\mathrm{K} 2$ and omission of the primary K2 antiserum or GAD-6 antibody. No labeling of neuronal cell bodies, processes, or terminals was observed under these conditions.

\section{Electron microscopy}

Tissue preparation. P1 rat pups were anesthetized by ether inhalation and subsequently perfused intracardially with $150 \mathrm{ml}$ of a fixative solution containing $2 \%$ paraformaldehyde and $2.5 \%$ glutaraldehyde in $0.12 \mathrm{M}$ sodium phosphate buffer, $\mathrm{pH}$ 7.3. The brains were removed and postfixed by immersion in the same fixative overnight at $4^{\circ} \mathrm{C}$. The following day, the brains were rinsed in sodium phosphate buffer for $1.5 \mathrm{hr}$, and coronal sections $(60 \mu \mathrm{m})$ of forebrain that contained the hippocampal formation were cut on a vibratome.

Immunocytochemistry for GAD65. Vibratome sections were processed with pre-embedding immunoperoxidase methods for GAD65 localization. Methods for electron microscopic immunolabeling for GAD65 were similar to those used for light microscopy, except that vibratome sections were initially processed for $30 \mathrm{~min}$ in $1 \%$ sodium borohydride to reduce nonspecific binding of antibody to the sections and to improve matrix permeability (Kosaka et al., 1986), GAD-6 antibody was used at a 1:50 dilution, and sections were incubated in biotinylated horse anti-mouse $\operatorname{IgG}$ for $2 \mathrm{hr}$.

In preparation for electron microscopy, sections were incubated in $1 \%$ osmium tetroxide in sodium phosphate buffer, $\mathrm{pH} 7.4$ for 50 min at $4^{\circ} \mathrm{C}$ and then dehydrated in a graded ethanol series. Sections were subsequently flat-embedded in Durcupan resin between acetate sheets and polymerized at $56^{\circ} \mathrm{C}$ for $24 \mathrm{hr}$. Regions of CA1, CA3, and the dentate gyrus that included the principal cell body layers and the apical dendritic fields were cut out and re-embedded on premade Durcupan blocks. Ultrathin sections from the superficial face of each block were cut with an ultramicrotome and collected on nickel mesh grids. Sections were then stained with uranyl acetate and lead citrate and examined with a Zeiss C10 electron microscope.

\section{RESULTS}

Developmental patterns of GAD67-containing neurons

GAD67-containing neurons were detected as early as E17-E18 in the developing hippocampus. These neurons were most prominent within the hippocampal marginal zone (prospective stratum radiatum and stratum lacunosum/moleculare) of CA1 (Fig. 1A,B).

Figure 1. GAD67-containing neurons in coronal sections of the developing hippocampal formation at E18 and E19. A, At E18, a prominent population of GAD67-containing neurons is present within the hippocampal marginal zone $(h M Z)$. These GAD67-positive neurons appear to be in continuity with the GAD67-labeled neurons of the neocortical marginal zone $(c M Z)$. Positively labeled neurons are also dispersed throughout the subplate $(S P)$ and lower intermediate zone $(L I Z)$. B, At higher magnification, the cell bodies of GAD67-containing neurons within the hippocampal marginal zone at E18 are clearly delineated. Several of the labeled neurons within this zone are located immediately adjacent to the developing pyramidal cell layer $(P)$. The labeled structures in the lower left corner are red blood cells that exhibit endogenous peroxidase activity. $C$, At E19, GAD67-containing neurons now occupy positions within the CA1 and CA3 hippocampal marginal zones and the dentate marginal zone (dMZ). The positively labeled neurons appear as a single row in the dentate marginal zone. Scale bars: $A, 100 \mu \mathrm{m} ; B, C, 50 \mu \mathrm{m}$. 

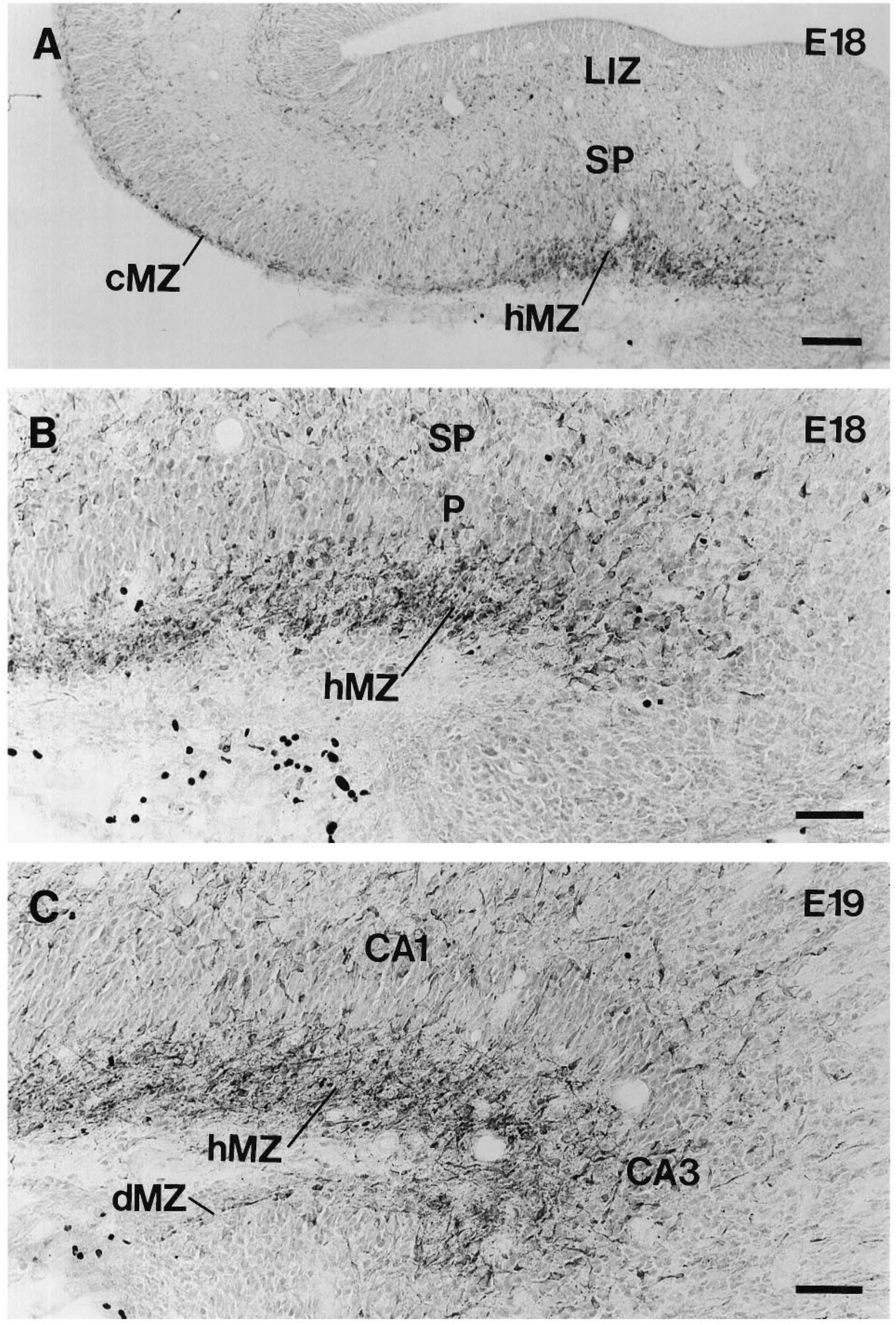
The GAD67-labeled neurons were distributed throughout the hippocampal marginal zone and thus formed a distinct broad band of labeled neurons that was located immediately adjacent to the developing pyramidal cell layer (Fig. 1B).

At this earliest time of detection, the GAD67-positive neurons within the hippocampal marginal zone were in continuity with the GAD67-labeled neurons of the neocortical marginal zone (Fig. $1 A$ ) but occupied a wider region and thus were more prominent than those of the neocortical marginal zone. This immunohistochemical continuity with the neocortical marginal zone persisted throughout the remaining period of embryonic development.

At E17-E18, GAD67-labeled cells were also present within a subplate-like region (part of the future stratum oriens) and the lower intermediate zone (future white matter) of the CA1 field (Fig. $1 A$ ) but were less prominent than those within the marginal zone. Relatively few positively labeled neurons were detected in the pyramidal cell layer (Fig. $1 B$ ).

By E19, GAD67-immunoreactive neurons occupied positions within both the CA1 and CA3 hippocampal marginal zones (Fig. $1 C)$ and within the subplate-like region of these fields. At this age, GAD67-positive neurons first became evident within the dentate gyrus and, as in the hippocampus, were located mainly within the marginal zone (prospective molecular layer) (Fig. 1C). Within this region, the immunoreactive neurons appeared as a very narrow row of cells.

At E20, GAD67-containing cell bodies within the hippocampal and dentate marginal zones were more striking and abundant than at any other developmental age tested. Within all hippocampal fields, the labeled cell bodies were located throughout much of the marginal zone and extended to the border of the pyramidal cell layer (Fig. $2 A, B$ ). Similarly, in the dentate gyrus, the GAD67positive neurons occupied positions throughout the marginal zone, with many concentrated slightly above the outer border of the developing granule cell layer (Fig. $2 A, B$ ). These labeled neurons formed a wider band than at E19.

The GAD67-immunoreactive cells within the hippocampal and dentate marginal zones from E17 to E20 exhibited the morphological features of neurons. Their cell bodies and presumptive dendritic processes were often visible (Fig. 2B), and they had variable sizes and shapes and process orientations. Many of the labeled cells within the dentate marginal zone appeared elongated in shape, were aligned with their long axis parallel to the developing granule cell layer, and possessed horizontally oriented processes (Fig. 2B, arrows). Other labeled neurons within the marginal zones displayed only a very thin rim of cytoplasmic staining, and this made them more difficult to detect and characterize.

This pattern of GAD67 labeling at E20, with a prominence of labeled neurons in the marginal zones or future dendritic regions and only a limited number of positive cells in the principal cell layers, was quite different from the adult pattern of cell body localization (compare Fig. $3 A$ and $B$ ). In the CA1 field of the adult hippocampus, low densities of GAD67-containing neurons were found within the dendritic regions of strata radiatum and lacunosum/moleculare, whereas high densities were present in the stratum pyramidale and at the interface between the strata radiatum and lacunosum/moleculare (Fig. 3B). Likewise, in the mature dentate gyrus, relatively few labeled neurons were distributed throughout the molecular layer, but a moderate number occupied positions within the innermost part of the granule cell layer (Fig. $3 B)$. Furthermore, most GAD-positive neurons that occupied positions within the dendritic regions of the adult hippocampal formation did not lie immediately adjacent to the apical regions of the principal cell body layers. Although it is likely that the immunohistochemical methods did not detect all GAD67-containing cell bodies in the adult, in situ hybridization studies of GAD67 mRNA-containing cell bodies in the adult hippocampal formation have revealed a similar distribution of positive neurons (Houser and Esclapez, 1994).

At E21, there was a distinct change in the structures that were labeled for GAD67 within the hippocampal formation. GAD67containing cell bodies became considerably less evident, and a large plexus of GAD67-containing processes began to occupy a substantial portion of the hippocampal and dentate marginal zones (Fig. 4A). Many of the positive processes within this meshwork were located immediately adjacent to the pyramidal and granule cell layers. A few GAD67-positive processes also extended across the widths of the CA1 and CA3 pyramidal cell layers, but otherwise, the cell body layers were relatively free of immunoreactive structures (Fig. 4A).

Although cell body labeling was not prominent at E21, occasional GAD67-containing cell bodies could be detected within the meshwork of processes in the marginal zones (Fig. 4A). A few labeled cells were also dispersed throughout the developing stratum oriens, stratum pyramidale, and hilus.

At P1, the pattern of labeling resembled that at E21, and GAD67-containing fibers with periodic varicosities were strikingly evident (Fig. 4B). Fibers with occasional swellings occupied a large portion of the presumptive hippocampal and dentate dendritic fields, although the densities of labeled processes were substantially lower in the molecular regions immediately adjacent to the hippocampal fissure (Fig. 4B). The hippocampal CA1 dendritic field included the developing stratum radiatum and stratum lacunosum/moleculare, although, at this early postnatal age, the border between the lamina was not yet evident. This massive terminal-like plexus was particularly prominent within the CA3 field of the hippocampus, and many of these positively labeled fibers with swellings were located immediately adjacent to the principal cell body layer. Thus, in CA3, the labeled fibers extended throughout the future stratum lucidum as well as the previously mentioned dendritic layers. Within the dentate gyrus, the molecular layer dendritic region was relatively narrow at this early age. Although not easily detectable, a few GAD67containing cell bodies were present within the plexus of fine fibers and varicosities in both the hippocampus and dentate gyrus (Fig. 4B).

\section{Developmental patterns of GAD65-containing neurons}

In general, the developmental patterns of GAD65 in the hippocampus and dentate gyrus paralleled those of GAD67, and the similarities between the patterns of GAD65- and GAD67-labeled neurons were more striking than the differences. First, the ages at which GAD65-containing neurons were first detected were the same as those for GAD67 (E17-E18 in the hippocampus and E19 in the dentate gyrus). Also, the early-appearing GAD65containing neurons had similar distributions to the GAD67labeled neurons and were evident throughout the hippocampal and dentate marginal zones, with many occupying positions adjacent to the principal cell body layers. The cell bodies of GAD65containing neurons were most evident at E20 (Fig. 5) as were those of the GAD67-containing neurons. Finally, a change in the GAD65 staining pattern from a predominance of cell body labeling to a plexus of fibers and terminal-like swellings occurred between E20 and P1, just as it did for GAD67.

Although the patterns of GAD65- and GAD67-containing neu- 

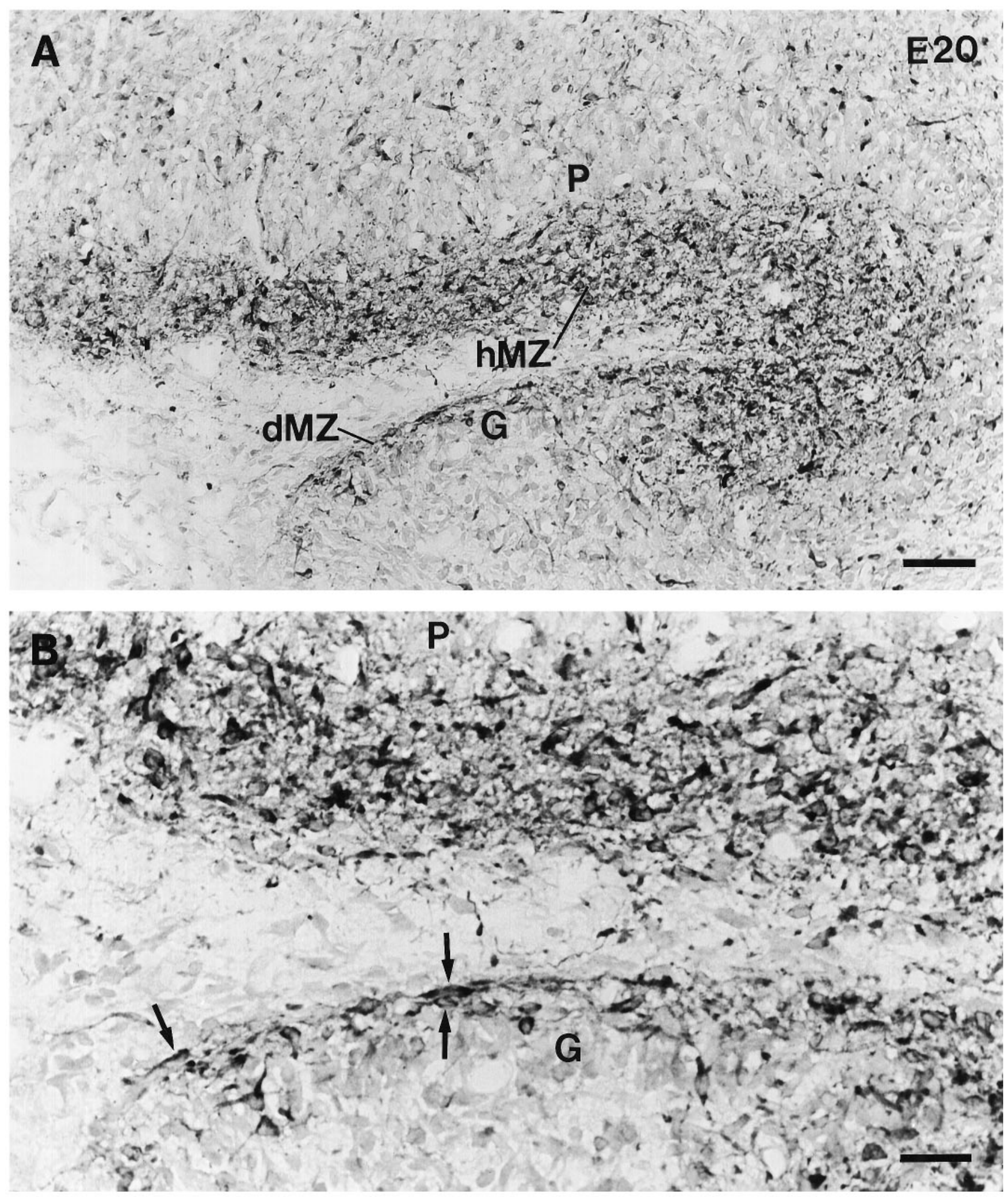

Figure 2. GAD67-containing neurons in coronal sections of the developing hippocampal formation at E20. A, At E20, GAD67-containing cell bodies within the hippocampal and dentate marginal zones $(h M Z$ and $d M Z)$ are even more striking and abundant than at earlier ages (compare with Fig. $1 B, C)$. Within the dentate marginal zone, many of the positively labeled cells are concentrated slightly above the outer border of the developing granule cell layer $(G)$. Labeled neurons extend throughout the hippocampal marginal zone and form a clear border with the immediately adjacent pyramidal cell layer $(P)$. $B$, A high-magnification photomicrograph of the CA1 and dentate marginal zones shown in $A$ demonstrates the morphology of the GAD67-immunoreactive cells within these regions. The labeled neurons have variable sizes and shapes and process orientations, but several within the dentate marginal zone exhibit fusiform shapes, are aligned with their long axis parallel to the granule cell layer, and possess horizontally oriented processes (arrows). The close proximity of the GAD67-containing neurons to the pyramidal $(P)$ and granule $(G)$ cell body layers is also evident. Scale bars: $A, 50 \mu \mathrm{m} ; B, 25 \mu \mathrm{m}$. 

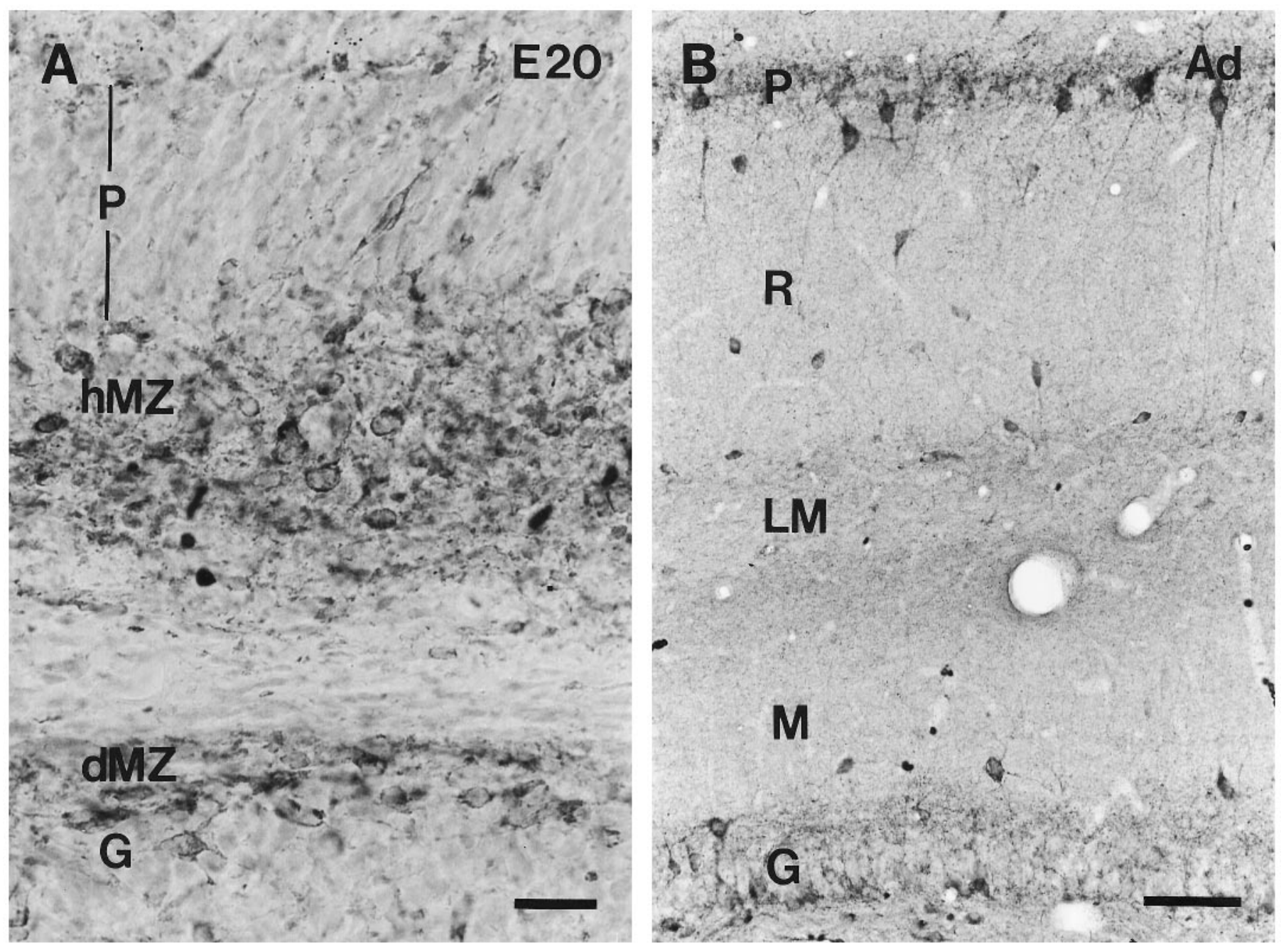

Figure 3. Comparison of the GAD67 cell body labeling patterns in coronal sections of the developing $(A)$ and mature $(B)$ hippocampal formation. For comparison of the laminar patterns, the sections are shown at different magnifications with approximate alignments of the pyramidal and granule cell layers. $A$, At E20, GAD67-containing cell bodies are highly concentrated throughout much of the marginal zones, the future dendritic regions, of the CA1 field of the hippocampus $(h M Z)$ and dentate gyrus $(d M Z)$ and extend to the borders of the pyramidal $(P)$ and granule $(G)$ cell layers. Relatively few labeled neurons are present within these layers. $B$, In the CA1 field of the adult $(A d)$ hippocampus, low densities of GAD67-containing neurons are found within the dendritic regions of strata radiatum $(R)$ and lacunosum/moleculare $(L M)$, whereas higher densities are present in the stratum pyramidale $(P)$ and at the interface between the strata radiatum and lacunosum/moleculare. Likewise, in the dentate gyrus, relatively few labeled neurons are distributed throughout the molecular layer $(M)$, whereas moderate numbers occupy positions within the granule cell layer $(G)$. It is also apparent that as the hippocampal formation matures, the relative proportions of the areas that are occupied by dendritic regions have increased, whereas the proportions occupied by principal cell layers, particularly the pyramidal cell layer, have decreased (compare $A$ and $B$ ). Scale bars: $A, 25 \mu \mathrm{m} ; B, 150 \mu \mathrm{m}$.

rons were very similar, some subtle differences in labeling were observed. The relative abundance of GAD-containing cell bodies often appeared slightly higher when labeled with the GAD67 antiserum than when labeled with the GAD65 antibody. In contrast, the massive terminal-like plexus, which occupied a large portion of the hippocampal and dentate dendritic regions at $\mathrm{P} 1$, appeared to be even more extensive when labeled with the GAD65 antibody than when labeled with the antiserum for GAD67. These differences were observed consistently but were subtle and thus may not be evident in all photomicrographs.

The pattern of terminal-like labeling for both GAD isoforms at early developmental ages differed considerably from the adult terminal labeling pattern. This difference was particularly striking for GAD65 in the CA3 field of the hippocampus (compare Fig. $6 A$ with $6 B$ ). At $\mathrm{P} 1$, the fine fibers with periodic swellings filled a large portion of the CA3 dendritic field, and many of the fibers occupied positions immediately adjacent to the pyramidal cell layer (Fig. 6A). Very few GAD65-containing terminals were evident in this layer. In the adult, GAD65-labeled terminals were most prominent within the stratum pyramidale where they were highly concentrated around the cell bodies of the pyramidal cells (Fig. 6B, arrows), and labeled terminals were considerably less abundant in the adjacent dendritic region, the stratum lucidum (Fig. 6B).

\section{Ultrastructural characteristics of GAD65-containing processes}

Following the light microscopic observations of a rich field of GAD-containing fibers and terminal-like structures within the developing hippocampal and dentate dendritic regions at early postnatal ages (Fig. 7A), the ultrastructural features of these processes were examined with electron microscopy. A general 

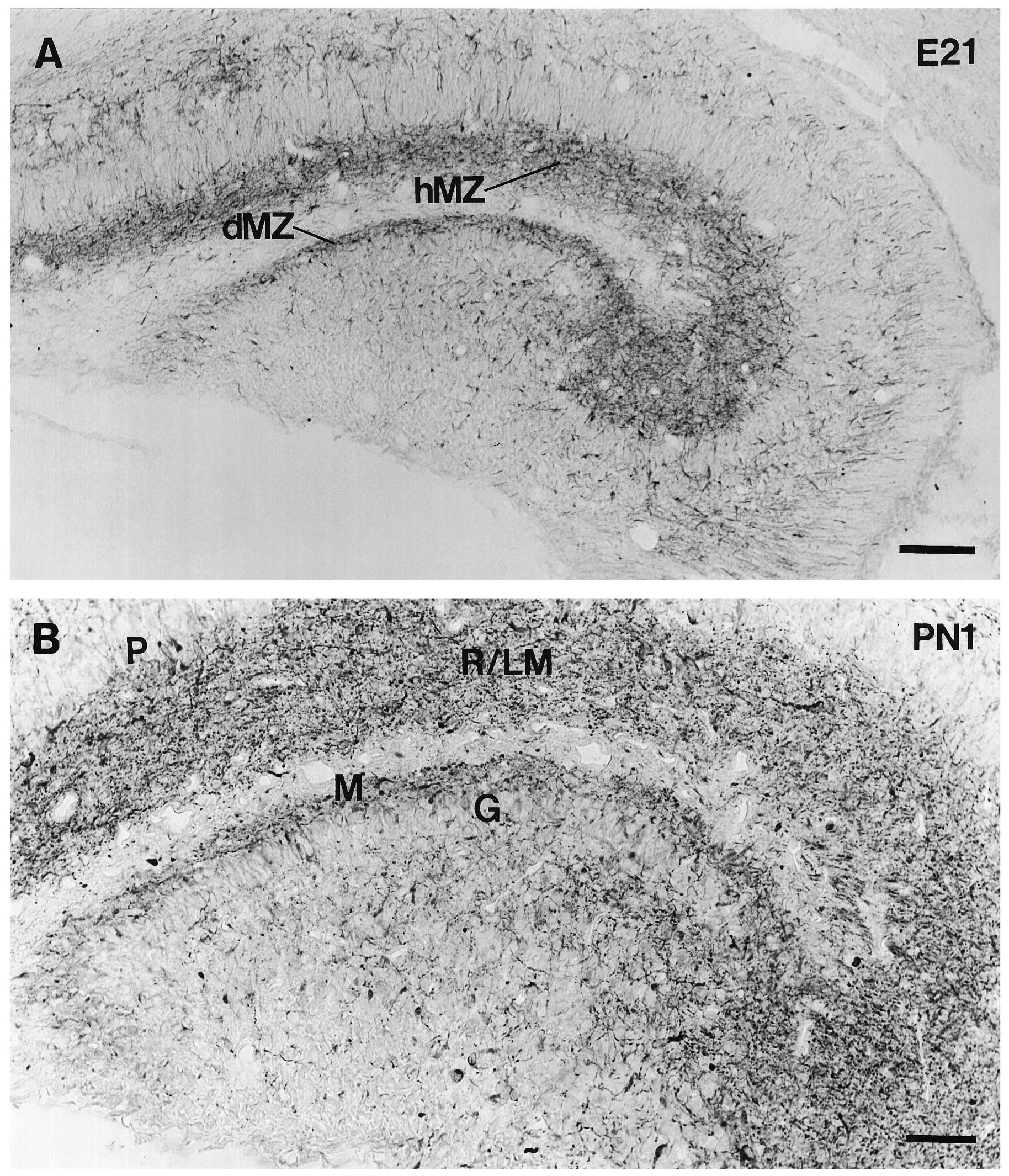

Figure 4. GAD67-containing neurons in coronal sections of the developing hippocampal formation at E21 and P1. A, At E21, the cell bodies of GAD67-containing neurons are less evident than at E20, but a plexus of GAD67-containing processes now occupies a substantial portion of the hippocampal and dentate marginal zones $(h M Z$ and $d M Z)$. B, By P1, the GAD67-containing fine fibers with periodic varicosities are extensive. The GAD67 fibers with occasional swellings occupy a large portion of the presumptive hippocampal and dentate dendritic fields, the strata radiatum and lacunosum/moleculare $(R / L M)$ and dentate molecular layer $(M)$. Many of these terminal-like structures lie immediately adjacent to the pyramidal $(P)$ and granule $(G)$ cell layers. Scale bars: $A, 100 \mu \mathrm{m} ; B, 50 \mu \mathrm{m}$. 


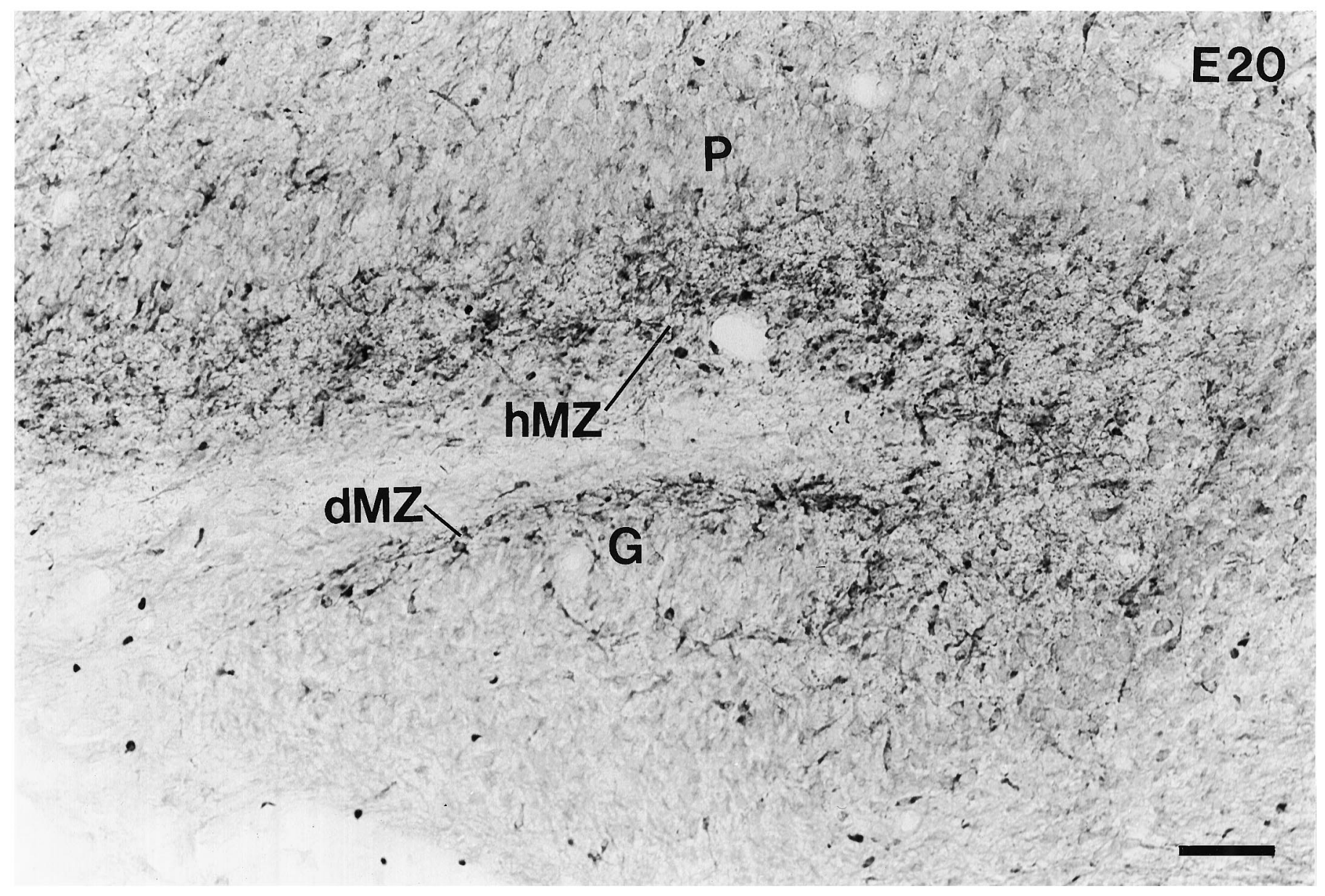

Figure 5. GAD65-containing neurons in a coronal section of the developing hippocampal formation at E20. GAD65-containing cell bodies are quite prominent throughout the hippocampal and dentate marginal zones ( $h M Z$ and $d M Z)$, with many positive neurons occupying positions immediately adjacent to the principal cell body layers. This pattern of cell body localization is similar to the pattern of GAD67-containing neurons at E20 (compare with Fig. $2 A)$. Very few labeled cells are detected within the pyramidal $(P)$ and granule $(G)$ cell layers. Scale bar, $50 \mu \mathrm{m}$.

survey of GAD65-labeled structures in the dendritic regions of CA1, CA3, and the dentate gyrus was conducted at P1.

Numerous GAD-labeled processes were found in the most proximal dendritic regions of the hippocampus and dentate gyrus, whereas relatively few were observed in the principal cell body layers. Many of the labeled profiles resembled axonal processes and contained large numbers of round vesicles that had the appearance of synaptic vesicles (Fig. 7B). The immunoreactivity within these structures was consistently concentrated near such vesicles. In some of the processes, vesicle-associated immunoreactivity was dispersed relatively homogeneously throughout much of their cytoplasm; however, in other structures, immunoreaction product was highly concentrated at specific vesicle-filled sites (Fig. $7 B, C)$. Such profiles resembled developing GAD-labeled processes that have been described in other brain regions (McLaughlin et al., 1975; Gotow and Sotelo, 1987).

A large number of the labeled axon-like processes were closely apposed to dendritic profiles and were often intercalated between or wrapped around these structures (Fig. $7 B, D$ ). In many instances, synaptic-like vesicles and GAD immunoreactivity were concentrated at specific sites within the axon-like processes, and these regions were closely apposed to dendritic profiles (Fig. $7 B, C$ ) as well as immature or developing processes (Fig. 7C). Definitive synapses were generally not observed between such
GAD65-labeled structures and dendritic profiles in our nonserial section analysis. However, in some instances, distinct sites of contact that resembled developing synapses could be identified (Fig. 7C). Occasionally, the vesicle-filled profiles corresponded to more mature axon terminals, which contained high concentrations of vesicles and mitochondrial profiles and appeared to form synaptic contacts (Fig. 7D). Thus, electron microscopic observations confirm the axon-like appearance of the GAD65-containing processes and demonstrate that the immunoreactive structures vary in their degree of maturity.

\section{DISCUSSION}

\section{Early appearance of GAD67 and GAD65 in the developing hippocampal formation}

The present study demonstrates that GAD67 and GAD65 can be detected at very early stages in the development of the rat hippocampal formation. At E17-E18, when GAD-containing neurons are first detected, the hippocampal primordium has just become evident (Bayer and Altman, 1974). Previous developmental studies have not described GAD-containing neurons in the hippocampus and dentate gyrus until P2-P5 (Seress and Ribak, 1988; Nitsch et al., 1990). However, early-appearing GABA neurons have been observed in the rat and mouse hippocampal formation, and their distributions appear to be similar to those of 

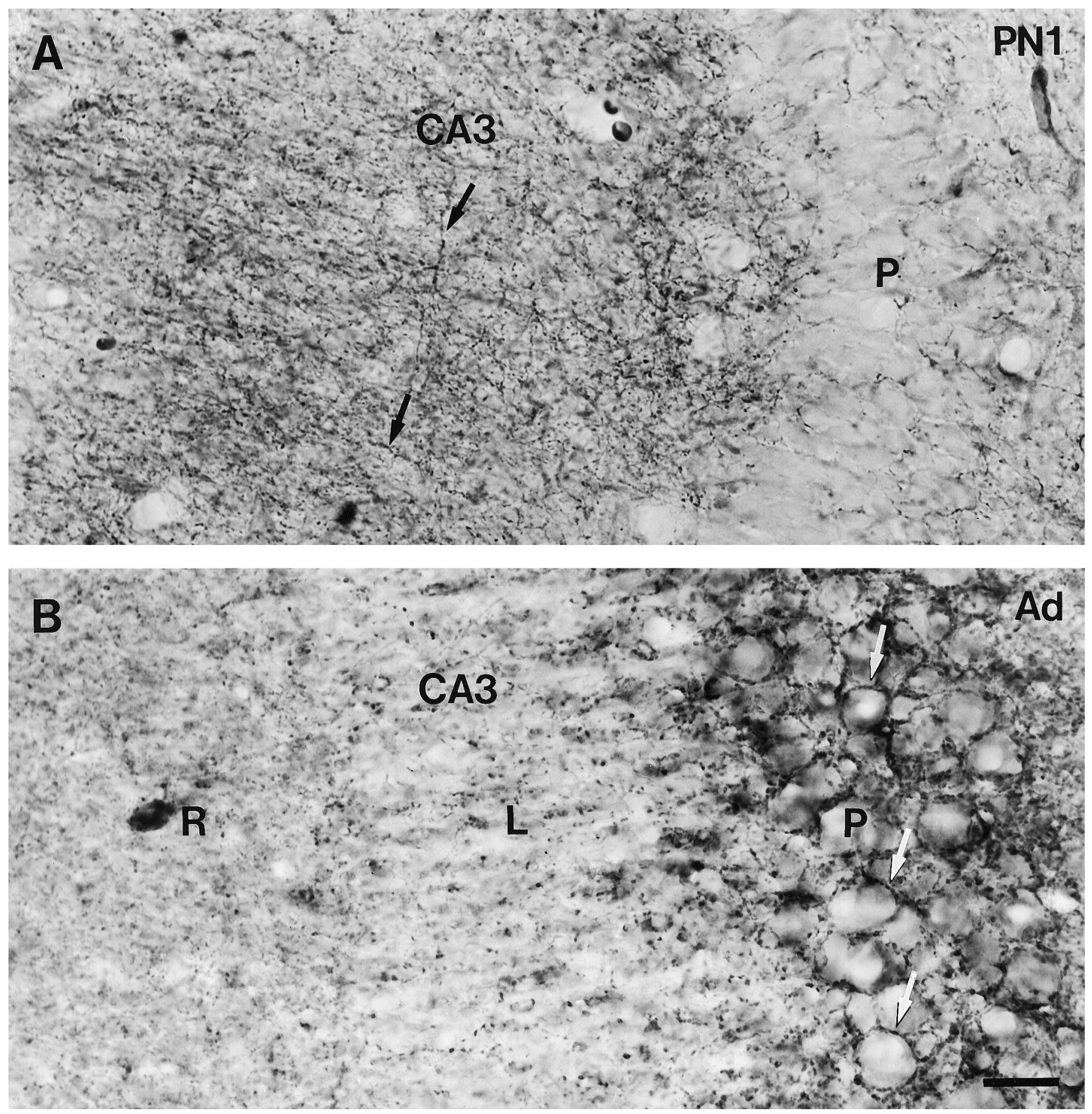

Figure 6. Comparison of the GAD65 labeling patterns in coronal sections of the developing $(A)$ and mature $(B)$ CA3 field of the hippocampus. $A$, At P1, fine fibers with periodic swellings fill a large portion of the CA3 dendritic field, with many occupying positions immediately adjacent to the pyramidal cells $(P)$. Several of these terminal-like structures have the appearance of boutons en passant (arrows). Very few labeled terminals are evident in the pyramidal cell layer. $B$, In the adult $(A d)$, GAD65-labeled terminals are most prominent within the pyramidal cell layer $(P)$, where they are concentrated around the cell bodies of the pyramidal cells (arrows). Labeled terminals are considerably less numerous within the adjacent dendritic region, the stratum lucidum $(L)$. A moderate amount of punctate labeling is evident within the stratum radiatum $(R)$. Scale bar (shown in $B$ ), $25 \mu \mathrm{m}$.

the GAD-labeled neurons in the present study (Lauder et al., 1986; Rozenberg et al., 1989; Soriano et al., 1994). The early presence of GAD and GABA in similar populations of hippocampal neurons suggests that GAD is likely to be involved in the synthesis of GABA even at very early stages of hippocampal development, and thus it does not appear necessary to propose an alternative pathway for GABA synthesis during early stages of development in the hippocampus (Lauder et al., 1986; Swann et al., 1989).

The presence of GAD67- and GAD65-containing neurons at E17 in the hippocampus and E19 in the dentate gyrus appears to parallel and, in some cases, precede the generation and arrival of 

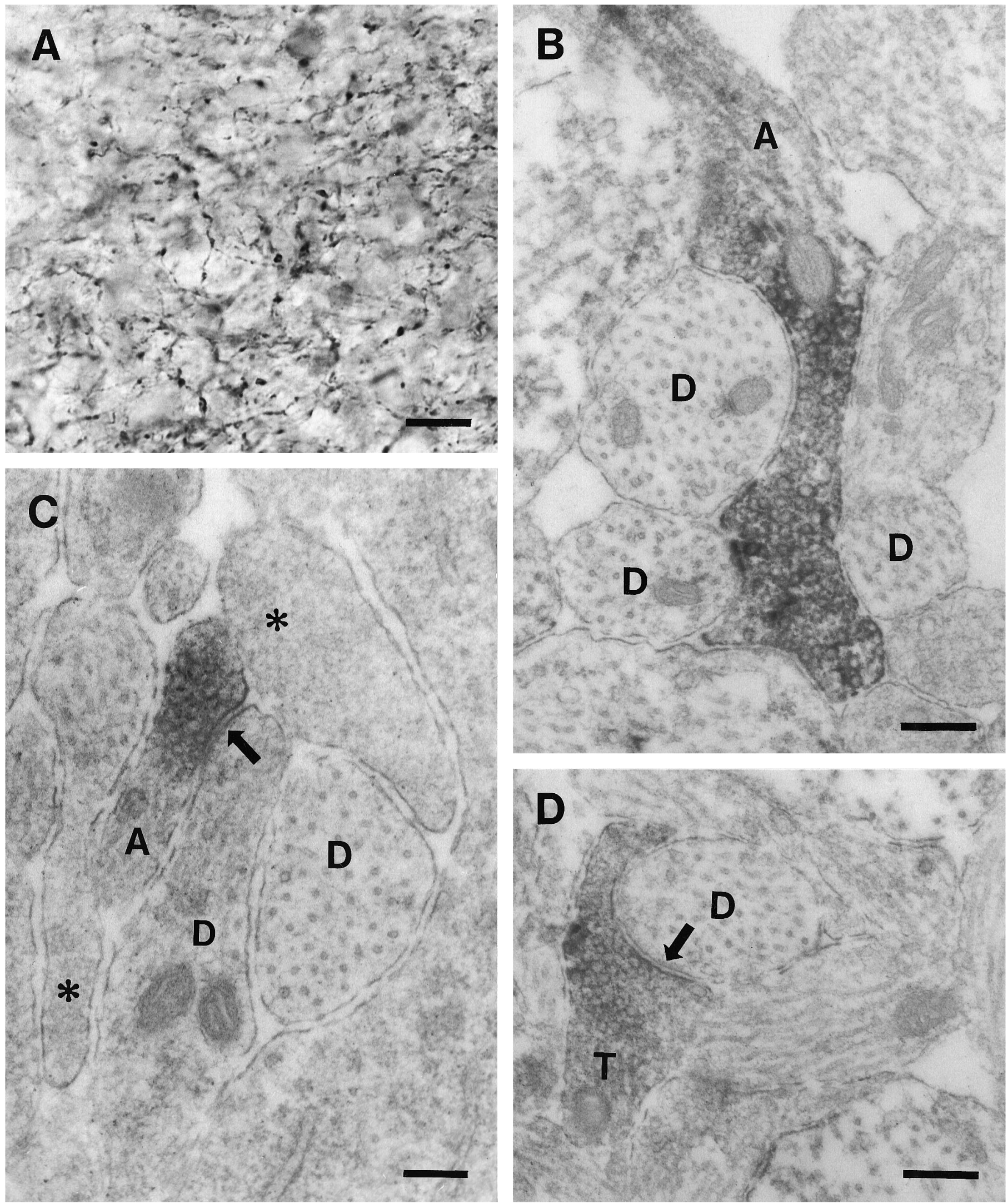

Figure 7. Light and electron microscopic characteristics of GAD65-immunoreactive fibers in P1 hippocampus. $A$, Light microscopy demonstrates numerous fine fibers with periodic swellings within the developing dendritic region of CA3. The remaining panels demonstrate ultrastructural features of such fibers in the various hippocampal fields. $B$, A GAD65-labeled axon-like process $(A)$ contains a large number of vesicles and courses between several dendritic profiles $(D)$ of the CA3 field. Immunoreactivity is highly concentrated in vesicle-filled regions of the process. $C$, GAD65 immunoreactivity is concentrated at a vesicle-filled site within an axon-like process $(A)$ in the molecular layer of the dentate gyrus. This site is in close contact (arrow) 
many of the pyramidal and granule cells, the principal cells of the hippocampal formation. Previous autoradiographic studies have indicated that the majority of the pyramidal cells are generated from E17 to E19 (E16 to E18 with our birthdating system) and do not settle into their appropriate positions until several days later (Schlessinger et al., 1978; Bayer, 1980; Altman and Bayer, 1990a,b), and a large percentage of granule cells are not generated until postnatal ages (Altman and Das, 1965; Bayer and Altman, 1974; Schlessinger et al., 1975; Bayer, 1980; Stanfield and Cowan, 1988; Altman and Bayer, 1990c). Thus, the presence of GAD-containing neurons before a large number of the principal cells of the hippocampal formation suggests that these earlyappearing neurons may influence the early development of this brain region.

\section{Similarities in the patterns of GAD67 and GAD65 expression in the developing hippocampal formation}

The patterns of GAD67 and GAD65 expression exhibited several similar features. First, the initial times of detection of the two proteins within the developing hippocampal formation were identical. This was an unexpected finding, because several studies of other developing brain regions, such as the cerebellum, striatum, and spinal cord, have detected GAD67 or its mRNA before that of GAD65 and its associated message (Greif et al., 1991, 1992; Behar et al., 1993). This has led to the suggestion of different functional roles for the two GAD isoforms during development (Greif et al., 1991). Our detection of both GAD67 and GAD65 at E17 within the developing hippocampal formation indicates that a sequential expression of the two proteins is not a general principle of GABA system development in all brain regions. The present studies cannot determine whether the two GADs have different functional roles during development but suggest that GAD65, as well as GAD67, is likely to contribute to GABA synthesis and thus play a role in early development.

The distribution patterns for the two GAD proteins within the developing hippocampal formation were also very similar. From E17 to E20, both GAD67 and GAD65 were concentrated in neuronal cell bodies within the marginal zones of the hippocampus and dentate gyrus. Similarly, from E21 to P1, both proteins had comparable distributions, because they were concentrated primarily in fine processes with periodic varicosities within the presumptive dendritic regions. These findings suggest that most of the labeled hippocampal and dentate neurons contain both GAD proteins and that the proteins are present in neuronal cell bodies as well as processes with terminal-like varicosities.

Although many similarities exist, there were subtle differences in the staining patterns for the two GAD isoforms. Many cell bodies were labeled more prominently with the K2 antiserum that primarily recognizes GAD67 than with the GAD6 antibody that recognizes GAD65. In contrast, GAD-containing processes with terminal-like structures were labeled more readily with the antibody to GAD65 than with the antiserum to GAD67. These findings imply that a greater proportion of GAD67 than GAD65 is localized to cell bodies, whereas a larger proportion of GAD65 than GAD67 is concentrated in fine processes and varicosities. Such subtle differences in the localization patterns for GAD67 and GAD65 are consistent with those observed in the adult CNS (Kaufman et al., 1991; Esclapez et al., 1994).

With the present immunohistochemical reagents, we cannot rule out the possibility that some of the GAD67 labeling at the embryonic and early postnatal ages could be attributable to the presence of the $25 \mathrm{kDa}$ and $44 \mathrm{kDa}$ embryonic GAD67 proteins, which recently have been detected within the developing rodent brain and spinal cord (Behar et al., 1993; Szabo et al., 1994). The functional significance of these two proteins during development has not been determined, but the $44 \mathrm{kDa}$ form of GAD67, like the adult form, is capable of synthesizing GABA, whereas the $25 \mathrm{kDa}$ form is considered to be a leader peptide (Szabo et al., 1994). Our preliminary RT-PCR studies of the developing hippocampal formation indicate that at E18-E20, the adult GAD67 message is quite abundant, whereas the embryonic GAD67 message is present at relatively low levels (Lawless GM, Dupuy ST, Tobin AJ, Houser CR, unpublished observations). Thus, it is likely that the adult form of GAD67 is the predominant form within the developing hippocampal formation. Also, our findings indicate that GAD65 initially appears within the hippocampal formation at the same time as GAD67, and there has been no reported evidence for an embryonic form of GAD65. Thus, one might expect that it is the adult form of GAD67 that is expressed in concert with GAD65 in the late embryonic and early postnatal hippocampal formation.

\section{Distinct features of the GAD-containing neurons in the developing hippocampal formation}

Several features of the GAD-containing neurons within the developing hippocampal formation were distinct from those of the adult. The first was a striking difference in the locations of GADlabeled cell bodies in the hippocampal formation at embryonic and adult ages. From E17 to E20, numerous GAD-positive cells occupied a large region of the marginal zones or future dendritic fields, and relatively few existed within the principal cell body layers, where GAD-positive neurons are frequently concentrated in the adult (Barber and Saito, 1976; Ribak et al., 1978; Seress and Ribak, 1983; Mugnaini and Oertel, 1985; Babb et al., 1988; Woodson et al., 1989).

A second distinct feature of the GAD localization patterns in the developing hippocampus was an unexpected shift from a predominance of GAD-containing cell bodies in the future dendritic regions at E20 to a meshwork of GAD-positive processes and terminal-like structures within these same regions at E21-P1. This change occurred quite rapidly, within $1 \mathrm{~d}$ of the maximal presence of the GAD-containing marginal zone population, and the pattern of labeled terminals did not resemble the typical distribution of terminals that has been reported previously for the early stages of GABA synaptogenesis in the hippocampal formation. Most previous immunohistochemical studies have not reported GAD- or GABA-positive boutons before P5 and, furthermore, have described them as occupying typical adult-like pericellular locations around pyramidal and granule cell somata rather than filling the dendritic fields (Lübbers and Frotscher, 1988; Rozenberg et al., 1989; Seress et al., 1989). However, Lübbers and Frotscher (1988) also described a striking concen-

with one of several dendritic profiles $(D)$ in the region. The labeled process is also located in close proximity to several undifferentiated or developing neuronal profiles, which have a paucity of organelles (asterisks). $D$, Some immunolabeled profiles within the dendritic regions exhibit features of mature axon terminals $(T)$, as illustrated by the high concentration of vesicles, the presence of a mitochondrial profile, and the establishment of a prototypic synaptic contact (arrow) with a dendrite $(D)$ of the CA3 field. Scale bars: $A, 10 \mu \mathrm{m} ; B, 0.3 \mu \mathrm{m} ; C, 0.2 \mu \mathrm{m} ; D, 0.3 \mu \mathrm{m}$. 
tration of GAD-positive punctate structures within the inner molecular layer at P5 and noted that this pattern differed from that of the adult.

The presently observed shift in GAD localization from predominantly cell body to terminal labeling also occurs in the neocortical marginal zone (future layer I) from E21 to P1 (Dupuy ST, Houser CR, unpublished observations). Similarly, Wolff et al. (1984) reported an increase in the density of GAD-immunoreactive processes, some of which were thought to resemble axons, in layer I of the neocortex at P1.

We interpret the change in the GAD labeling pattern within the hippocampal and neocortical marginal zones as a shift in the intracellular distribution of the GAD67 and GAD65 proteins from cell bodies to terminal-like structures at late prenatal to early postnatal ages. This suggestion is supported by our in situ hybridization studies, which indicate that GAD mRNAcontaining cell bodies are still present in the same dendritic regions as the terminal-like varicosities at early postnatal ages (Dupuy et al., 1994). In addition, several immunohistochemical studies of GABA localization have demonstrated labeled neurons within the hippocampal and dentate dendritic regions at early postnatal times (Rozenberg et al., 1989; Soriano et al., 1994). Also, in preliminary reports of intracellular labeling with biocytin, Ben-Ari et al. (1994) have indicated that the axonal networks of some putative interneurons are already well developed by $\mathrm{P} 2$.

Although we suggest that local GABA neurons give rise to many of the GAD-labeled fibers within the hippocampal and dentate dendritic fields, this does not exclude the possibility that extrinsic sources may contribute to the GAD-positive processes. One extrinsic source could be the septum, because mature GABAergic septohippocampal projections are known to terminate within hippocampal and dentate dendritic regions (Freund and Antal, 1988), and GADcontaining fine fibers were detected in the fimbria at late prenatal ages (Dupuy ST, Houser CR, unpublished observations). Previous studies of the development of the septohippocampal projection indicate that a large number of these fibers reach the hippocampus and dentate by late prenatal and early postnatal ages (Linke and Frotscher, 1993; Super and Soriano, 1994), the time of appearance of the extensive GAD-containing fiber plexus within the hippocampal formation. However, many of these early septohippocampal projections are likely to be cholinergic (Linke and Frotscher, 1993; Super and Soriano, 1994).

The fate of the early-appearing population of GAD-containing neurons in the hippocampal formation is not known. Our findings of unique locations and early appearance of these neurons within the developing hippocampal and dentate marginal zones are consistent with the suggestion that they are a separate, possibly transient, population from the mature GAD population. A transient existence of this early-appearing GABA population has also been suggested by Rozenberg et al. (1989). Alternate hypotheses are that the GAD-labeled neurons at E20 will become the permanent GAD-containing neurons of the adult hippocampal formation or that two separate populations of GAD-containing neurons are present within the hippocampal formation at E20, a transient population and one that corresponds to the permanent GAD neurons. It is also conceivable that the early-appearing neurons are a separate population from the adult GABAergic population but only transiently express GAD. Although the transient expression of both GAD and GABA has been detected in neurons of other developing brain regions (Schnitzer and Rusoff, 1984; Redburn and Keith, 1987; Ma et al., 1992a,b; Messersmith and Redburn, 1992), this seems less likely for the early GAD- containing neurons of the hippocampal formation, because few non-GABA interneurons have been identified in the dendritic regions of the adult hippocampus.

\section{Functional significance of early-appearing GAD- containing neurons in the developing hippocampal formation}

The prominent group of GAD-containing neurons in the developing hippocampal formation appears to be similar to the marginal and subplate neurons of the neocortex. Indeed, the GADcontaining neurons of the hippocampus are in continuity with GAD-containing neurons of the neocortical marginal and subplate zones at E17-E20, and it is likely that they play similar roles in the development of their respective brain regions. These may include helping to establish the appropriate cortical cytoarchitecture (Marín-Padilla, 1984a,b; Luskin and Shatz, 1985; Del Río et al., 1995a; Ogawa et al., 1995) and serving as transient recipients for incoming afferents, as has been demonstrated for the subplate neurons of the neocortex (for review, see Shatz et al., 1988; Allendoerfer and Shatz, 1994) and proposed for the earlyappearing GABA neurons and calretinin-containing neurons of the murine hippocampus (Super and Soriano, 1994; Del Río et al., 1995b).

Other important influences of these early GAD-containing neurons could come from the direct actions of GABA on nearby neurons. As has been suggested by in vitro studies, these could include trophic actions such as the promotion of neuronal differentiation and neurite outgrowth (Spoerri and Wolff, 1981; Hansen et al., 1984; Spoerri, 1988; Michler, 1990; Barbin et al., 1993), the modulation of synapse formation (Madtes and Redburn, 1983; Meier et al., 1984; Messersmith and Redburn, 1993), and the induction of chemotaxis (Behar et al., 1996). The GADcontaining fibers with periodic varicosities that were identified in the present study could serve as particularly effective morphological substrates for such actions in vivo.

The present identification of an early abundance of GADcontaining elements and the marked difference in their distribution from that of the adult suggest that GABA neurons could have unique and changing roles during development of the hippocampal formation. These findings complement previous observations of changes in the physiological actions of GABA during hippocampal development. Interestingly, in hippocampal slices from early postnatal animals, the application of GABA produces depolarizing effects in CA1 and CA3 pyramidal cells, in contrast to the normal hyperpolarizing effects observed in the adult (Mueller et al., 1984; Janigro and Schwartzkroin, 1988; Ben-Ari et al., 1989; Cherubini et al., 1991). This depolarization can, in turn, lead to an increase in intracellular calcium, which might then promote neuronal development (Barbin et al., 1993; Ben-Ari et al., 1994; Obrietan and van den Pol, 1995). The labeled terminal-like structures identified in the present study at early postnatal times are likely to be the natural source of GABA for such functions in the immature hippocampus.

\section{REFERENCES}

Allendoerfer KL, Shatz CJ (1994) The subplate, a transient neocortical structure: its role in the development of connections between thalamus and cortex. Annu Rev Neurosci 17:185-218.

Altman J, Bayer SA (1990a) Mosaic organization of the hippocampal neuroepithelium and the multiple germinal sources of dentate granule cells. J Comp Neurol 301:325-342.

Altman J, Bayer SA (1990b) Prolonged sojourn of developing pyramidal cells in the intermediate zone of the hippocampus and their settling in the stratum pyramidale. J Comp Neurol 301:343-364. 
Altman J, Bayer SA (1990c) Migration and distribution of two populations of hippocampal granule cell precursors during the perinatal and postnatal periods. J Comp Neurol 301:365-381.

Altman J, Das GD (1965) Autoradiographic and histological evidence of postnatal hippocampal neurogenesis in rats. J Comp Neurol 124:319-336.

Amaral DG, Kurz J (1985) The time of origin of cells demonstrating glutamic acid decarboxylase-like immunoreactivity in the hippocampal formation of the rat. Neurosci Lett 59:33-39.

Babb TL, Pretorius JK, Kupfer WR, Brown WJ (1988) Distribution of glutamate-decarboxylase-immunoreactive neurons and synapses in the rat and monkey hippocampus: light and electron microscopy. J Comp Neurol 278:121-138.

Barber R, Saito K (1976) Light microscopic visualization of GAD and GABA-T in immunocytochemical preparations of rodent CNS. In: GABA in nervous system function (Roberts E, Chase TN, Tower DB, eds), pp 113-132. New York: Raven.

Barbin G, Pollard H, Gaiarsa JL, Ben-Ari Y (1993) Involvement of $\mathrm{GABA}_{\mathrm{A}}$ receptors in the outgrowth of cultured hippocampal neurons. Neurosci Lett 152:150-154.

Bayer SA (1980) Development of the hippocampal region in the rat. I. Neurogenesis examined with ${ }^{3} \mathrm{H}$-thymidine autoradiography. J Comp Neurol 190:87-114.

Bayer SA, Altman J (1974) Hippocampal development in the rat. Cytogenesis and morphogenesis examined with autoradiography and lowlevel X-irradiation. J Comp Neurol 158:55-80.

Behar TN, Schaffner A, Laing P, Hudson L, Komoly S, Barker J (1993) Many spinal cord cells transiently express low molecular weight forms of glutamic acid decarboxylase during embryonic development. Dev Brain Res 72:203-218.

Behar TN, Li Y-X, Tran HT, Ma W, Dunlap V, Scott C, Barker JL (1996) GABA stimulates chemotaxis and chemokinesis of embryonic cortical neurons via calcium-dependent mechanisms. J Neurosci 16:1808-1818.

Ben-Ari Y, Cherubini E, Corradetti R, Gaiarsa JL (1989) Giant synaptic potentials in immature rat CA3 hippocampal neurones. J Physiol (Lond) 416:303-325.

Ben-Ari Y, Tseeb V, Raggozzino D, Khazipov R, Gaiarsa JL (1994) $\gamma$-Aminobutyric acid (GABA): a fast excitatory transmitter which may regulate the development of hippocampal neurones in early postnatal life. Prog Brain Res 102:261-273.

Chang Y-C, Gottlieb DI (1988) Characterization of the proteins purified with monoclonal antibodies to glutamic acid decarboxylase. J Neurosci $8: 2123-2130$.

Cherubini E, Gaiarsa JL, Ben-Ari Y (1991) GABA: an excitatory transmitter in early postnatal life. Trends Neurosci 14:515-519.

Del Río JA, Martínez A, Fonseca M, Auladell C, Soriano E (1995a) Glutamate-like immunoreactivity and fate of Cajal-Retzius cells in the murine cortex as identified with calretinin antibody. Cereb Cortex 5:13-21.

Del Río JA, Soriano E, Super H, Frotscher M, Heimrich B (1995b) Characteristics and functions of Cajal-Retzius cells in organotypic slice cultures of hippocampus and neocortex. Soc Neurosci Abstr 21:1779.

Dupuy ST, Houser CR (1995) Early appearance and generation of a prominent population of GAD67-containing neurons in the developing rat hippocampal formation. Soc Neurosci Abstr 21:307.

Dupuy ST, Havens BA, Houser CR (1994) Early presence of GADcontaining interneurons in the developing granule cell layer of the rat dentate gyrus. Soc Neurosci Abstr 20:1320.

Erlander MG, Tobin AJ (1991) The structural and functional heterogeneity of glutamic acid decarboxylase: a review. Neurochem Res 16:215-226.

Erlander MG, Tillakaratne NJK, Feldblum S, Patel N, Tobin AJ (1991) Two genes encode distinct glutamate decarboxylases. Neuron 7:91-100.

Esclapez M, Tillakaratne NJK, Kaufman DL, Tobin AJ, Houser CR (1994) Comparative localization of two forms of glutamic acid decarboxylase and their mRNAs in rat brain supports the concept of functional differences between the forms. J Neurosci 14:1834-1855.

Freshney RI (1987) Culture of animal cells: a manual of basic technique. New York: Wiley.

Freund TF, Antal M (1988) GABA-containing neurons in the septum control inhibitory interneurons in the hippocampus. Nature 336:170-173.

Gotow T, Sotelo C (1987) Postnatal development of the inferior olivary complex in the rat. IV. Synaptogenesis of GABAergic afferents, ana- lyzed by glutamic acid decarboxylase immunocytochemistry. J Comp Neurol 263:526-552.

Greif KF, Erlander MG, Tillakaratne NJK, Tobin AJ (1991) Postnatal expression of glutamate decarboxylases in developing rat cerebellum. Neurochem Res 16:235-242.

Greif KF, Tillakaratne NJK, Erlander MG, Feldblum S, Tobin AJ (1992) Transient increase in expression of a glutamate decarboxylase (GAD) mRNA during the postnatal development of the rat striatum. Dev Biol 152:158-164.

Hansen GH, Meier E, Schousboe A (1984) GABA influences the ultrastructure composition of cerebellar granule cells during development in culture. Int J Dev Neurosci 2:247-257.

Houser CR, Esclapez M (1994) Localization of mRNAs encoding two forms of glutamic acid decarboxylase in the rat hippocampal formation. Hippocampus 4:530-545.

Janigro D, Schwartzkroin PA (1988) Effects of GABA and baclofen on pyramidal cells in the developing rabbit hippocampus: an in vitro study. Dev Brain Res 41:171-184.

Kaufman DL, McGinnis JF, Krieger NR, Tobin AJ (1986) Brain glutamate decarboxylase cloned in $\lambda \mathrm{gt}-11$ : fusion protein produces $\gamma$-aminobutyric acid. Science 232:1138-1140.

Kaufman DL, Houser CR, Tobin AJ (1991) Two forms of the gammaaminobutyric acid synthetic enzyme glutamate decarboxylase have distinct intraneuronal distributions and cofactor interactions. J Neurochem 56:720-723.

Kobayashi Y, Kaufman DL, Tobin AJ (1987) Glutamic acid decarboxylase cDNA: nucleotide sequence encoding an enzymatically active fusion protein. J Neurosci 7:2768-2772.

Kosaka T, Nagatsu I, Wu J-Y, Hama K (1986) Use of high concentrations of glutaraldehyde for immunocytochemistry of transmittersynthesizing enzymes in the central nervous system. Neuroscience 18:975-990.

Lauder JM, Han VKM, Henderson P, Verdoorn T, Towle AC (1986) Prenatal ontogeny of the GABAergic system in the rat brain: an immunocytochemical study. Neuroscience 19:465-493.

Linke R, Frotscher M (1993) Development of the rat septohippocampal projection: tracing with DiI and electron microscopy of identified growth cones. J Comp Neurol 332:69-88.

Luskin MA, Shatz CJ (1985) Studies of the earliest generated cells of the cat's visual cortex: cogeneration of subplate and marginal zones. J Neurosci 5:1062-1075.

Lübbers K, Frotscher M (1988) Differentiation of granule cells in relation to GABAergic neurons in the rat fascia dentata. Combined Golgi/EM and immunocytochemical studies. Anat Embryol (Berl) 178:119-127.

Lübbers K, Wolff JR, Frotscher M (1985) Neurogenesis of GABAergic neurons in the rat dentate gyrus: a combined autoradiographic and immunocytochemical study. Neurosci Lett 62:317-322.

Ma W, Behar T, Barker J (1992a) Neuroepithelial cells in the rat spinal cord express glutamate decarboxylase immunoreactivity in vivo and in vitro. J Comp Neurol 325:257-270.

Ma W, Behar T, Maric D, Maric I, Barker JL (1992b) Transient expression of GABA immunoreactivity in the developing rat spinal cord. J Comp Neurol 325:271-290.

Madtes Jr P, Redburn DA (1983) GABA as a trophic factor during development. Life Sci 33:979-984.

Marín-Padilla M (1984a) Neurons of layer I. A developmental analysis. In: Cerebral cortex, Vol I (Peters A, Jones EG, eds), pp 447-478. New York: Plenum.

Marín-Padilla M (1984b) Early ontogenesis of the human cerebral cortex. In: Cerebral cortex, Vol VII (Peters A, Jones EG, eds), pp 1-30. New York: Plenum.

McLaughlin BJ, Wood JG, Saito K, Roberts E, Wu J-Y (1975) The fine structural localization of glutamate decarboxylase in developing axonal processes and presynaptic terminals of rodent cerebellum. Brain Res 85:355-371.

Meier E, Drejer J, Schousboe A (1984) GABA induces functionally active low-affinity GABA receptors on cultured cerebellar granule cells. J Neurochem 43:1737-1744.

Messersmith EK, Redburn DA (1992) $\gamma$-Aminobutyric acid immunoreactivity in multiple cell types of the developing rabbit retina. Vis Neurosci 8:201-211.

Messersmith EK, Redburn DA (1993) The role of GABA during development of the outer retina in the rabbit. Neurochem Res 18:463-470. 
Michler A (1990) Involvement of GABA receptors in the regulation of neurite growth in cultured embryonic chick tectum. Int J Dev Neurosci 8:463-472.

Mueller AL, Taube JS, Schwartzkroin PA (1984) Development of hyperpolarizing inhibitory postsynaptic potentials and hyperpolarizing response to $\gamma$-aminobutyric acid in rabbit hippocampus studied in vitro. J Neurosci 4:860-867.

Mugnaini E, Oertel WH (1985) An atlas of the distribution of GABAergic neurons and terminals in the rat CNS as revealed by GAD immunohistochemistry. In: Handbook of chemical neuroanatomy, Vol 4, GABA and neuropeptides in the CNS, part I (Björklund A, Hökfelt T, eds), pp 436-608. Amsterdam: Elsevier.

Nitsch R, Bergmann I, Küppers K, Mueller G, Frotscher M (1990) Late appearance of parvalbumin immunoreactivity in the development of GABAergic neurons in the rat hippocampus. Neurosci Lett 118:147-150.

Obrietan K, van den Pol AN (1995) GABA neurotransmission in the hypothalamus: developmental reversal from $\mathrm{Ca}^{2+}$ elevating to depressing. J Neurosci 15:5065-5077.

Ogawa M, Miyata T, Nakajima K, Yagyu K, Seike M, Ikenaka K, Yamamoto H, Mikoshiba K (1995) The reeler gene-associated antigen on Cajal-Retzius neurons is a crucial molecule for laminar organization of cortical neurons. Neuron 14:899-912.

Redburn DA, Keith ME (1987) Developmental alterations in retinal GABAergic neurons. In: Neurotrophic activity of GABA during development (Redburn DA, Schousboe A, eds), pp 79-108. New York: Liss.

Ribak CE, Vaughn JE, Saito K (1978) Immunocytochemical localization of glutamic acid decarboxylase in neuronal somata following colchicine inhibition of axonal transport. Brain Res 140:315-332.

Rozenberg F, Robain O, Jardin L, Ben-Ari Y (1989) Distribution of GABAergic neurons in the late fetal and early postnatal rat hippocampus. Dev Brain Res 50:177-187.

Schlessinger AR, Cowan WM, Gottlieb DI (1975) An autoradiographic study of the time of origin and the pattern of granule cell migration in the dentate gyrus of the rat. J Comp Neurol 159:149-176.

Schlessinger AR, Cowan WM, Swanson LW (1978) The time of origin of neurons in Ammon's horn and the associated retrohippocampal fields. Anat Embryol 154:153-173.

Schnitzer J, Rusoff AC (1984) Horizontal cells of the mouse retina contain glutamic acid decarboxylase-like immunoreactivity during early development. J Neurosci 4:2948-2955.

Seress L, Ribak CE (1983) GABAergic cells in the dentate gyrus appear to be local circuit and projection neurons. Exp Brain Res 50:173-182.

Seress L, Ribak CE (1988) The development of GABAergic neurons in the rat hippocampal formation: an immunocytochemical study. Dev Brain Res 44:197-209.
Seress L, Frotscher M, Ribak CE (1989) Local circuit neurons in both the dentate gyrus and Ammon's horn establish synaptic connections with principal neurons in five day old rats: a morphological basis for inhibition in early development. Exp Brain Res 78:1-9.

Shatz CJ, Chun JJM, Luskin MB (1988) The role of the subplate in the development of the mammalian telencephalon. In: Cerebral cortex, Vol 7, Development and maturation of cerebral cortex (Jones EG, Peters A, eds), pp 35-58. New York: Plenum.

Soriano E, Cobas A, Fairén A (1986) Asynchronism in the neurogenesis of GABAergic and non-GABAergic neurons in the mouse hippocampus. Dev Brain Res 30:88-92.

Soriano E, Cobas A, Fairén A (1989a) Neurogenesis of glutamic acid decarboxylase immunoreactive cells in the hippocampus of the mouse. I. Regio superior and regio inferior. J Comp Neurol 281:586-602.

Soriano E, Cobas A, Fairén A (1989b) Neurogenesis of glutamic acid decarboxylase immunoreactive cells in the hippocampus of the mouse. II. Area dentata. J Comp Neurol 281:603-611.

Soriano E, Del Río JA, Martínez A, Super H (1994) Organization of the embryonic and early postnatal murine hippocampus. I. Immunocytochemical characterization of neuronal populations in the subplate and marginal zone. J Comp Neurol 342:571-595.

Spoerri PE (1988) Neurotrophic effects of GABA in cultures of embryonic chick brain and retina. Synapse 2:11-22.

Spoerri PE, Wolff JR (1981) Effect of GABA administration on murine neuroblastoma cells in culture. I. Increased membrane dynamics and formation of specialized contacts. Cell Tissue Res 218:567-579.

Stanfield BB, Cowan WM (1988) The development of the hippocampal region. In: Cerebral cortex, Vol 7, Development and maturation of cerebral cortex (Peters A, Jones EG, eds), pp 91-131. New York: Plenum.

Super H, Soriano E (1994) The organization of the embryonic and early postnatal murine hippocampus. II. Development of entorhinal, commissural, and septal connections studied with the lipophilic tracer DiI. J Comp Neurol 344:101-120.

Swann JW, Brady RJ, Martin DL (1989) Postnatal development of GABA-mediated synaptic inhibition in rat hippocampus. Neuroscience 28:551-561.

Szabo G, Katarova Z, Greenspan R (1994) Distinct protein forms are produced from alternatively spliced bicistronic glutamic acid decarboxylase mRNAs during development. Mol Cell Biol 14:7535-7545.

Wolff JR, Böttcher H, Zetzsche T, Oertel WH, Chronwall BM (1984) Development of GABAergic neurons in rat visual cortex as identified by glutamate decarboxylase-like immunoreactivity. Neurosci Lett 47:207-212.

Woodson W, Nitecka L, Ben-Ari Y (1989) Organization of the GABAergic system in the rat hippocampal formation: a quantitative immunocytochemical study. J Comp Neurol 280:254-271. 